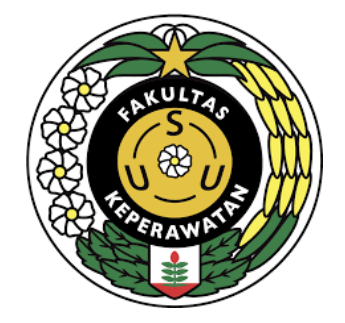

\title{
"MODEL KEPEMIMPINAN HASTA BRATA SEBAGAI SIFAT KEPEMIMPINAN YANG EFEKTIF DALAM KEPERAWATAN"
}

\section{DISUSUN OLEH :}

\author{
RINI DEBORA SILALAHI \\ 197046015 \\ rinisilalahi19@gmail.com
}

\author{
PROGRAM STUDI MAGISTER KEPERAWATAN \\ FAKULTAS KEPERAWATAN \\ UNIVERSITAS SUMATERA UTARA \\ MEDAN \\ 2019
}




\section{PRAKATA}

Puji dan syukur penulis ucapkan kepada Tuhan Yang Maha Esa, atas berkat dan anugerahNya sehingga penulis dapat menyelesaikan kajian yang berjudul Model Kepemimpinan Hasta Brata Sebagai Sifat Kepemimpinan yang efektif dalam keperawatan. Kajian ini merupakan salah satu tugas dari mata kuliah kepemimpinan dalam keperawatan.

Pada kesempatan ini penulis menyampaikan rasa terima kasih yang kepada Bapak Roymond Simamora, S.Kep, Ns, M.Kep selaku dosen pembimbing yang telah memberikan bimbingan dan petunjuk demi terselesainya kajian ini. 


\section{Daftar Isi}

\begin{tabular}{|c|c|}
\hline \multicolumn{2}{|l|}{$\begin{array}{lc} & \text { Halaman } \\
\text { Halaman Judul } & \text { i }\end{array}$} \\
\hline & $\mathrm{i}$ \\
\hline Prakata.. & ii \\
\hline Daftar Isi. & iii \\
\hline Abstrak. & iv \\
\hline Bab 1. Pendahuluan & 1 \\
\hline 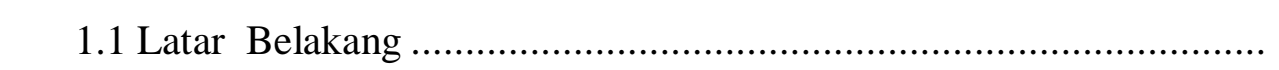 & 1 \\
\hline 1.2 Rumusan Masalah ... & 2 \\
\hline 1.3 Tujuan Penelitian.... & 2 \\
\hline 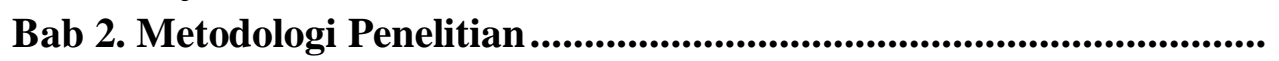 & 3 \\
\hline 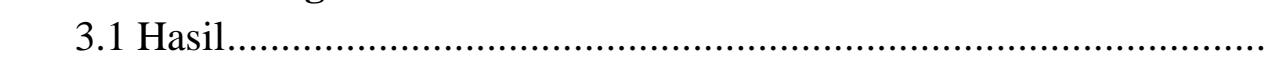 & 3 \\
\hline 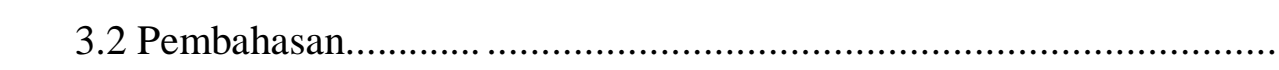 & 4 \\
\hline 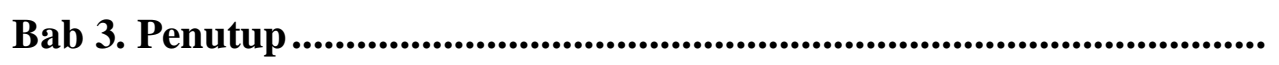 & 5 \\
\hline Referensi & 6 \\
\hline
\end{tabular}


Judul : Model Kepemimpinan Hasta Brata Sebagai Sifat Kepemimpinan yang Efektif Dalam Keperawatan

Penulis : : Rini Debora Silalahi

NIM : 197046015

Jurusan : Program Studi Magister Keperawatan

Tahun Akademik : 2019/2020

\begin{abstract}
Abstrak
Kepemimpinan sangat berpengaruh pada pelayanan keperawatan di rumah sakit. Pemilihan gaya kepemimpinan yang diterapkan oleh kepala ruang dalam memimpin dan mengkoordinir perawat pelaksana sangat mempengaruhi kinerja perawat dalam pemberian asuhan keperawatan. Gaya kepemimpinan erat kaitannya dengan budaya. Salah satu budaya yang berkaitan dengan konsep kepemimpinan adalah kepemimpinan Hasta Brata. Pendekatan yang dilakukan untuk melakukan identifikasi kepemimpinan Hasta Brata adalah dengan teori sifat (trait theory) dimana pendekatan yang dilakukan fokus pada pemimpin. Tujuan penelitian untuk mengidentifikasi gaya kepemimpinan hasta brata dalam penerapan kepemimpinan keperawatan yang efektif. Metodologi yang digunakan adalah fokus grup diskusi. Hasil yang diperoleh kearifan lokal budaya Jawa tentang kepemimpinan Hasta Brata dapat diterapkan sebagai pembelajaran kepemimpinan yang filosofis terhadap suatu organisasi yang bersifat dinamis, seperti pelayanan dalam suatu rumah sakit.
\end{abstract}

Kata Kunci: Gaya kepemimpinan, Budaya, Hasta Brata 


\section{BAB I}

\subsection{Latar Belakang}

Banyak masalah yang timbul karena ketidakmampuan pemimpin untuk mengorganisir anggotanya. Masalah yang muncul dapat mempengaruhi perawat dalam mengelola pasien di ruangan. Banyak perawat yang tidak hadir kerja karena ketidakharmonisan hubungan kerja dengan kepala ruangan. Misalnya kepala ruangan yang menyalahkan satu pihak tanpa adanya bukti. Oleh karena itu keberhasilan pemimpin tidak ditentukan oleh tinggi rendahnya pendidikan, namun lebih dikarenakan karena terciptanya komunikasi yang baik antar pemimpin dan anggota. Komunikasi yang baik mampu menciptakan rasa saling menghormati.

Kepemimpinan adalah sebuah relasi antara seseorang yang memiliki kemampuan lebih besar dibanding anggotanya untuk mempengaruhi orang lain dalam mencapai tujuan. Seorang pemimpin yang efektif tidak menggunakan kelebihannya untuk mengalahkan bawahannya, tetapi memotivasi bawahan untuk mampu mencapai tujuan sesuai dengan kapasitas yang dimiliki (Kadarman dan Udaya, 1994). Menurut La Monica, 1986 seorang pemimpin yang baik harus mampu menyatukan kemampuan masing-masing anggotanya.

Kepemimpinan merupakan hal yang penting yang mempengaruhi tingkat kinerja karyawan,dan dalam proses pencapaian tujuan, yakni motivasi. Motivasi mampu meningkatkan kinerja kerja sesorang sekitar 60-70\%. Dalam hal ini pemimpin harus memiliki pengetahuan tentang teori motivasi untuk mampu memotivasi para anggotanya. Persoalan yang muncul adalah praktik model kepemimpinan yang ditemui sekarang ini berbasis pada model-model yang berasal dari Amerika Serikat, Eropa, Jepang dan China sehingga diperlukan penafsiran-penafsiran dan adaptasi untuk menyesuaikan dengan kondisi dan kebudayaan lokal karena kepemimpinan merupakan salah satu wujud dari kebudayaan yang dianut oleh suatu masyarakat.

Menurut Poloma (2010) hasil proses budaya oleh masyarakat tersebut akan membentuk suatu realitas sosial setidaknya sebagian adalah produksi manusia, hasil proses budaya, termasuk penggunaan bahasa. Untuk mengatasi permasalahan-permasalahan tersebut, 
bangsa Indonesia sebenarnya telah memiliki warisan luhur dari nenek moyang. Dalam berbagai budaya daerah di Indonesia terdapat kekayaan yang tak ternilai, yaitu kekayaan nilai-nilai kearifan lokal berupa kepemimpinan dan berbagai kebijakan hidup untuk dijadikan pegangan para pemimpin. Dalam budaya Jawa, bentuk dan konsepsi kepemimpinan itu multi varian, bahkan setiap generasi memiliki corak yang berbeda. Meskipun demikian, konsep-konsep tersebut arahnya menuju sebuah paradigma keseimbangan. Ajaran kepemimpinan dan kebijakan hidup tersebut, umumnya diwariskan melalui karya sastra Jawa. Salah satu karya sastra Jawa yang memiliki relasi dengan konsep kepemimpinan adalah Hasta Brata, yang di dalamnya terdapat berbagai konsep kepemimpinan yang dicipta dengan penuh keteladanan yang diwujudkan dalam bentuk ajaran.

\subsection{Rumusan masalah}

Berdasarkan latar belakang di atas, rumusan masalah dalam kajian ini adalah Bagaimana hubungan kepemimpinan dalam keperawatan dengan Kearifan lokal Hasta Brata?

\subsection{Tujuan}

Tujuan dalam kajian ilmiah ini adalah untuk mengidentifikasi kearifal lokal Hasta Brata dalam kepemimpinan keperawatan. 


\section{BAB II}

\subsection{Metodologi}

Penelitian ini menggunakan metode fokus grup diskusi untuk memperkuat isu strategis dan juga solusi yang dijadikan sebagai dasar peneliti dalam menyusun rekomendasi kompetensi kepemimpinan kepala ruang sebagai upaya peningkatan motivasi dan kinerja perawat pelaksana.

2.2Hasil

Hasil menunjukkan bahwa faktor internal berpengaruh signifikan terhadap kompetensi kepemimpinan, faktor eksternal berpengaruh signifikan terhadap kompetensi kepemimpinan, kompetensi kepemimpinan berpengaruh signifikan terhadap motivasi, dan kompetensi kepemimpinan berpengaruh positif terhadap kinerja. Isu strategis yang didapatkan pada tahap ini yaitu faktor internal yang terdiri dari pengetahuan, keterampilan, dan nilai, faktor eksternal terdiri dari budaya organisasik, kompetensi kepemimpinan dan motivasi serta kinerja

\subsection{Pembahasan}

Gaya kepemimpinan yang berbeda merupakan cara seseorang memanfaatkan kekuatan yang tersedia untuk memimpin orang lain. Setiap pemimpin memiliki cara tersendiri. Seorang pemimpin yang efektif adalah seorang pemimpin yang dapat mempengaruhi orang lain agar dapat bekerja sama untuk mencapai hasil yang memuaskan dan terjadinya perubahan yang bermanfaat. Tidak ada gaya atau karakteristik kepemimpinan yang dapat dikatakan efektif tanpa mempertimbangkan situasi kultural, situasi kerja dan kebutuhan pekerja yang terus-menerus berubah dari waktu ke waktu. 
Berdasarkan hasil penelitian komponen faktor internal yang paling mempengaruhi kompetensi kepemimpinan adalah komponen nilai, nilai yang dimaksudkan adalah kompetensi kepemimpinan kepala ruang merupakan hal yang sangat penting dan menjadi acuan kepala ruang dalam melaksanakan peran dan fungsinya untuk peningkatan mutu pelayanan, selain itu kompetensi kepemimpinan kepala ruang memiliki nilai strategis bagi peningkatan motivasi dan kinerja perawat pelaksana. Seorang pemimpin dalam memotivasi orang lain harus tahu diri, mengevaluasi keyakinan, dan nilai-nilai pribadi (Bennis 1989 dalam Smith 2012). Nilai-nilai yang harus dimiliki oleh seorang pemimpin tertuang dalam suatu budaya Jawa yang dikenal dengan Hasta Brata.

Hasta Brata merupakan watak atau sifat utama yang diambil dari sifat alam. Hasta mempunyai arti delapan, sedangkan Brata mempunyai arti laku. Dapat diartikan juga bahwa Hasta Brata adalah delapan laku, watak atau sifat utama yang harus dipegang teguh dan dilaksanakan oleh seorang pemimpin atau siapa saja yang terpilih menjadi pemimpin (Yasasusastra, 2011). Berdasarkan konsep tersebut maka seorang pemimpin harus memiliki delapan sifat alam yaitu bumi, matahari, api, samudera, langit, angin, bulan, dan bintang. Delapan sifat alam tersebut mengandung makna seorang pemimpin harus memiliki sifat tegas, motivator, berani, berpandangan luas, melindungi, fleksibel, solutif dan panutan.

Perawat merupakan ujung tombak dari pelayanan kesehatan di Rumah Sakit, apabila kinerja unit dalam suatu organisasi/unit pelayanan kesehatan tinggi maka akan mempengaruhi kualitas dari organisasi tersebut, oleh sebab itu dibutuhkan leader atau kepala keperawatan yang mengetahui dan memiliki kompetensi kepemimpinan yang Hasta Brata untuk meningkatkan kinerja perawat dalam pemberian layanan asuhan keperawatan. 


\section{BAB III}

\subsection{Penutup}

Model kompetensi kepemimpinan kepala ruang dipengaruhi oleh faktor internal dan eksternal. Faktor internal merupakan faktor yang ada dalam diri pemimpin yang terdiri dari pengetahuan, keterampilan dan nilai, sedangkan faktor ekternal terdiri dari faktor bawahan (pendidikan) dan faktor organisasi (budaya organisasi). Penerapan model kompetensi kepemimpinan kepala ruang mempengaruhi motivasi dan kinerja perawat pelaksana.

Faktor internal seorang pemimpin tertuang dalam warisan budaya Jawa tentang Kepemimpinan Hasta Brata yang memberikan pandangan baru terhadap pembelajaran kepemimpinan yang filosofis. Dalam kepemimpinan keperawatan seorang leader dapat menggabungkan konsep kepemimpinan keperawatan secara umum dan konsep kepemimpinan dengan kearifan lokal yang ada.

Penggabungan dari kedua pemahaman tersebut menghasilkan konsep baru yang lebih efektif untuk peningkatan kompetensi kepemimpinan serta mengetahui sifat dan penerapan kepemimpinan yang adaptif dalam perubahan yang dinamis. Kedua konsep tersebut, yakni Hasta Brata dan teori kepemimpinan modern, akan menghasilkan konsep baru model kepemimpinan teori yang mungkin akan masih terus berkembang untuk meningkatkan outcome organisasi secara efektif. 


\section{Daftar Pustaka}

As'ad, Moh, Wahyu Jati, dan Mariana Virdaniaty. (2011). Studi Eksplorasi Konstrak Kepemimpinan Model Jawa: Asta Brata. Diakses pada tanggal 31 September 2019 dari http://jurnal.ugm.ac.id.

Candra, Putra Syah. (2017). Buku Ajar Manajemen Keperawatan. Bogor: In Media.

Dewi, Cahya Bania. (2013). Konsep Kepemimpinan Dalam Budaya Jawa di Comic Strip. Diakses pada tanggal 31 September 2019 dari http://jurnal.usu.ac.id.

Efendi, Fery dan Makhfudli. (2009). Keperawatan Kesehatan Komunitas. Jakarta: Salemba Medika.

Hudaya, Zuhdan dan Nugroho Sigit. (2013). Kearifan Lokl Budaya Jawa Sebagai Basis Model Kepemimpinan Yang Efektif. Diakses pada tanggal 30 September 2019 dari http://jp.feb.unsoed.ac.id.

Kuntoro, Agus. (2017). Buku Ajar Manajemen Keperawatan. Yogyakarta: Nuha Medika.

Mubarak, Iqbal Wahid. (2009). Sosiologi Untuk Keperawatan. Jakarta: Salemba Medika.

Mugianti, Sri. (2016). Manajemen dan Kepemimpinan Dalam Praktek Keperawatan. Jakarta: Kementrian Kesehatan Republik Indonesia.

Nursalam. (2016). Manajemen Keperawatan; Aplikasi Dalam Praktik Keperawatan. Jakarta: Salemba Medika.

Simamora, R.H. (2014). Buku Ajar Manajemen Keperawatan. Jakarta: Penerbit Buku Kedokteran EGC.

Simamora, R. H. (2013). Upaya Pembinaan Perawat Di Rumah Sakit Ngesti Waluyo Parakan Temanggung Jawa Tengah. Jurnal Keperawatan Soedirman,8(2).

Sumijatun. (2010). Konsep Dasar Menuju Keperawatan Profesional. Jakarta: Trans Info Media.

Sunaryo. (2015). Sosiologi Untuk Keperawatan. Jakarta: Bumi Medika.

Sari, Triani Mila. (2009). Hubungan Budaya Organisasi dan Gaya Kepemimpinan Kepala Ruangan Dengan Kinerja Perawat Pelaksana di Ruang Rawat Inap Rumah Sakit Daerah Raden Mattaher Jambi. Diakses pada tanggal 31 September 2019 dari http://lib.ui.ac,id.

Wilda, Syahrul. (2017). Filsafat Asta Brata; Implementasi Dalam Kepemimpinan. Diakses pada tanggal 31 September 2019 dari http://repository. uinjkt.ac.id 